\title{
AGO Austria recommendations for genetic testing of patients with ovarian cancer
}

\author{
Christian Marth · Michael Hubalek · Edgar Petru - Stephan Polterauer - Alexander Reinthaller · \\ Christian Schauer · Tonja Scholl-Firon · Christian F. Singer · Johannes Zschocke · Alain G. Zeimet
}

Published online: 25 June 2015

(C) The Author(s) 2015. This article is published with open access at Springerlink.com

\begin{abstract}
Summary In Austria, 700 women are diagnosed every year with ovarian carcinoma. Approximately $15 \%$ of the patients with epithelial ovarian cancer have a germline mutation in the BRCA1 or BRCA2 genes. The increased incidence of breast and/or ovarian cancer in genetically related family members has given rise to the term "hereditary breast and ovarian cancer syndrome" (HBOC). Some $25-55 \%$ of these in-family diseases are attributed to germline mutations of $B R C A 1$ or $B R C A 2$, and approximately $5-10 \%$ to other known tumor predisposition syndromes. The remaining persons may carry mutations in as yet unidentified genes. HBOC caused by BRCA1 and $B R C A 2$ mutations is an autosomal dominant disorder with high penetrance. $B R C A 1$ and $B R C A 2$ encode for socalled tumor suppressor proteins. Inherited functional
\end{abstract}

C. Marth, MD, PhD $(\bowtie) \cdot$ M. Hubalek · A. G. Zeimet

Clinic for Gynecology and Obstetrics,

Medical University of Innsbruck,

Anichstrasse 35, 6020 Innsbruck, Austria

e-mail: christian.marth@uki.at

E. Petru

Clinic for Gynecology and Obstetrics, Medical University of Graz, Graz, Austria

S. Polterauer · A. Reinthaller · C. F. Singer

Clinic for Gynecology, Clinical Department of General Gynecology and Gynecological Oncology, Medical University of Vienna,

Vienna, Austria

\section{Schauer}

Department of Gynecology,

Krankenhaus der Barmherzigen Brüder,

Graz, Austria

\section{T. Scholl-Firon}

Department of Gynecology and Obstetrics, Wilhelminenspital, Vienna, Austria

\section{J. Zschocke}

Division of Human Genetics, Medical University of Innsbruck, Innsbruck, Austria mutations of these genes cause loss of function of the respective allele. Loss of function of the second allele causes complete loss of the corresponding protein and facilitates the development of a malignancy.

The Association of Gynecologic Oncology recommends that testing for a germline mutation in $B R C A 1$ or $B R C A 2$ should be offered to all patients with epithelial ovarian cancer. When mutations in BRCA1, BRCA2, or other cancer-susceptibility genes have been identified, patients with ovarian carcinoma can be treated with new, innovative therapies. This recommendation is intended as a standard guideline for genetic testing of patients with an ovarian carcinoma.

Keywords Ovarian cancer $\cdot B R C A 1 \cdot B R C A 2 \cdot$ Mutation · PARP

Empfehlungen der Arbeitsgemeinschaft für gynäkologische Onkologie Österreich zur genetischen Testung von Patientinnen mit Ovarialkarzinom

Zusammenfassung In Österreich erkranken jedes Jahr etwa 700 Frauen an einem Ovarialkarzinom. Etwa $15 \%$ der Patientinnen mit epithelialem Ovarialkarzinom sind Träger einer Keimbahnmutation im BRCA1 - oder BRCA2Gen. Aufgrund des häufig gemeinsamen Vorkommens von Mamma- und Ovarialkarzinomen spricht man vom „hereditären Mamma- und Ovarialkarzinomsyndrom“ (HBOC). Etwa 25-55 \% dieser familiären Erkrankungen werden Keimbahnmutationen des BRCA1- oder BRCA2Gens zugeschrieben, etwa 5-10 \% anderen bekannten Tumordispositionssyndromen. Die verbleibenden Erkrankungen werden durch bisher nicht bekannte Gene erklärt. BRCA1- und BRCA2-Mutationen werden autosomal-dominant mit hoher Penetranz vererbt. Physiologischerweise kodieren $B R C A 1$ bzw. BRCA2 für sogenannte 
Tumorsuppressorproteine. Funktionelle Mutationen dieser Gene führen zum Ausfall des Allels. Ein Ausfall auch des zweiten Allels führt zum Verlust der entsprechenden Proteine und erleichtert die maligne Transformation.

Eine genetische Testung und Bestimmung einer Keimbahnmutation in BRCA1 oder BRCA2 soll allen Patientinnen mit epithelialem Ovarialkarzinom angeboten werden. Durch den Nachweis von Mutationen im Bereich sogenannter Krebssuszeptibilitätsgene (wie BRCA1 und BRCA2) können bei Patientinnen mit manifestem Ovarialkarzinom neue, innovative Therapien eingesetzt werden. Durch die vorliegende Empfehlung soll die genetische Testung von Patientinnen mit Ovarialkarzinom einheitlich definiert werden.

Schlüsselwörter Ovarialkarzinom • BRCA1 • BRCA2 • Mutation · PARP

\section{Breast carcinomas and ovarian carcinomas}

In its guideline issued in May 2011, the Austrian Society for Gynecology and Obstetrics took a standpoint on prevention and early diagnosis of breast and ovarian cancers in high-risk patients. From this recommendation, the indication for molecular genetic analysis of $B R C A 1$ and BRCA2 was defined [1]:

Indications for molecular genetic analysis of $B R C A 1$ and $B R C A 2$

\begin{tabular}{l} 
Two breast cancer cases before age of 50 years \\
Three breast cancer cases before age of 60 years \\
One breast cancer case before age of 35 years \\
One breast cancer case before age of 50 years and one ovarian cancer \\
case at any age \\
\hline Two ovarian cancer cases at any age \\
\hline Male and female breast cancer at any age
\end{tabular}

This remains the basis for recommending genetic testing and meets the criteria for the cost to be paid by the Austrian national medical insurance system.

In Tyrol, Austria, the German S3 Guideline was incorporated into the recommendations of the Tyrolean Working Group for Clinical Oncology (TAKO) [2].

\section{TAKO recommendations:}

\begin{tabular}{|l|}
\hline Only one affected person in a family \\
\hline Breast cancer with first occurrence before age of 35 years \\
\hline Bilateral breast cancer with first occurrence before age of 50 years \\
\hline Both breast and ovarian cancer at any age \\
\hline Multiple cases on the same side of a family \\
\hline Two women with breast cancer, one with first occurrence before age of 50 \\
years \\
\hline One woman with breast cancer and one woman with ovarian cancer \\
\hline Two women with ovarian cancer \\
\hline Three or more women with breast cancer \\
\hline One man with breast cancer and one woman with breast or ovarian cancer \\
\hline
\end{tabular}

In general, a greater than $10 \%$ prevalence of the mutation should be the threshold to recommend genetic testing. Even the very conservative National Institute for Health and Care Excellence recommends a genetic test at a calculated risk of $10 \%$ or more [3].

Until now, the costs for genetic testing in patients with an ovarian carcinoma have been covered only when the family history was positive, which meant that additional family members usually must have been diagnosed with ovarian and/or breast cancer. Recent findings, however, have shown that up to $15 \%$ of patients with epithelial ovarian cancer have germline mutations in BRCA1 or $B R C A 2[4,5]$. Half of these patients have no apparent family history for ovarian cancer. This may be due, on the one hand, to the absence of female relatives, and on the other hand, to the insufficient knowledge of the family medical history.

Germline mutations in $B R C A 1$ or $B R C A 2$ are associated with early-onset breast cancer. For ovarian cancer, the correlation with age is less clear, as $35 \%$ of the patients with hereditary ovarian cancer are of the age of $60+$ years at the time of diagnosis.

In addition to germline mutations, at least another $2-8 \%$ of ovarian cancers have somatic $B R C A 1$ and $B R C A 2$ mutations [5], so that up to $20 \%$ of patients with ovarian cancer have a $B R C A 1$ or $B R C A 2$ deficiency triggered by a mutation. In addition, it is also known that 9-14\% of nonmutated ovarian cancers bear an epigenetic silencing of the $B R C A 1$ gene due to promoter hypermethylation [6].

Identification of a BRCA mutation has many consequences. One of them is that patients with a mutationinduced BRCA dysfunction have better survival and respond better to platinum therapy. Furthermore, a BRCA germline mutation is also associated with a risk for other tumors, particularly breast cancer. Such patients can decide to undergo an intensive early detection program or prophylactic surgery. Identification of a germline mutation also provides important information for other family members and their potential tumor risk, and permits personalized preventive measures to be outlined for high-risk persons. Genetic testing has taken on special importance through the introduction of new therapeutic possibilities using so-called "PARP (Poly ADP ribose polymerase) inhibitors" that are particularly effective in the case of a BRCA1 or BRCA2 mutation [7].

New technologies such as "next general sequencing" reduce the cost of genetic testing and permit additional genes to be tested. Blood samples taken in two GOG studies (GOG 218 and GOG 262) were subjected to genetic testing and showed a BRCA1/2 mutation in $13.7 \%$ of the patients with ovarian carcinoma, as well as mutations in other genes, in particular BRIP1, PALB2, CHEK2, NBN, and $A T M$, in $5.6 \%$ of the patients [8]. The new testing methods pose special challenges for interpretation of the genetic data, knowledge of a wide range of cancer predispositions, and genetic counseling.

On the basis of these new findings, the Association of Gynecologic Oncology (AGO) Austria makes the following recommendations for women with ovarian cancer: 
1. Genetic testing for $B R C A 1$ or $B R C A 2$ germline mutations should be offered to all patients with an epithelial ovarian carcinoma. Patients with borderline ovarian tumors or nonepithelial ovarian tumors and who do not meet the criteria for hereditary breast and ovarian carcinoma cannot be expected to benefit from testing.

2. Before germline mutation analysis of $B R C A 1$ and $B R C A 2$ in genomic DNA, the patient must undergo formal genetic counseling with regard to the possibility of a hereditary predisposition and must give her written consent for testing. The test results must be explained to the patient in a second personal genetic counselling session by a Medical Geneticist or a medical specialist for the particular indication as defined by the Austrian Gentechnikgesetz (GTG, Genetic Engineering Act). Counselling must be concluded with a counselling letter that contains all relevant points of the discussion, including the relevance of the findings for the patient's family.

3. Before carrying out a genetic analysis of DNA isolated from tumor tissue that may potentially identify a germline mutation for example in $B R C A 1$ or $B R C A 2$, the patient must be informed of the potential relevance of the test results for herself or other family members and must give her written consent for the test (for download see: AGO patient information sheet at: www.ago-austria.at).

4. If a probable germline mutation is identified in the tumor tissue, the test results must be conveyed to the patient by genetic counseling in compliance with the Austrian GTG. The patient must be informed about the relevance of the test results for herself and other family members as well as the possibilities for further work-up, and she must be offered the opportunity for germline mutation testing in genomic DNA (typically isolated from blood).

5. In view of the great significance for prognosis and treatment, especially, for possible PARP inhibitor therapy, not only a test for germline mutation, using DNA from a blood sample, but also quality-controlled testing of the tumor material should be performed. In an effort to personalize medicine, the AGO explicitly sup- ports all innovative steps that promote the use of new technologies such as "next generation sequencing" to test for not only the two most common mutated genes, $B R C A 1$ and BRCA2, but also other genes involved in the homologous recombination repair of DNA as well as other relevant genes for ovarian cancer biology. In addition to testing solely for sequence alterations, assays should be developed in the future that also use, for example, epigenetic or functional analysis to better characterize tumor cells.

\section{Conflict of interest}

The authors declare that there are no actual or potential conflicts of interest related to this article.

\section{Open Access}

This article is distributed under the terms of the Creative Commons Attribution License which permits any use, distribution, and reproduction in any medium, provided the original author(s) and the source are credited.

\section{References}

1. Singer CF, Tea MK, Pristauz G, Hubalek M, Rappaport C, et al. Leitlinie zur Prävention und Früherkennung von Brustund Eierstockkrebs bei Hochrisikopatientinnen, inbesondere bei Frauen aus HBOC (Hereditary Breast and Ovarian Cancer) Familien. Wien Klin Wochenschr. 2012;124:334-9.

2. http://www.awmf.org/uploads/tx_szleitlinien/032045OL_k_S3_Brustkrebs_Mammakarzinom_Diagnostik_ Therapie_Nachsorge_2012-07.pdf; www.tako.or.at.

3. Cancer Research UK, Ovarian Cancer Key Facts, www. cancerresearchuk.org/cancer-info/cancerstats/keyfacts/ ovariancancer/.

4. Pal T, Permuth-Wey J, Betts JA, Krischer JP, Fiorica J, Arango $\mathrm{H}$, et al. BRCA1 and BRCA2 mutations account for a large proportion of ovarian carcinoma cases. Cancer. 2005;104:2807-16.

5. Ramus SJ, Gayther SA. The contribution of BRCA1 and BRCA2 to ovarian cancer. Mol Oncol. 2009;3:138-50.

6. Cunningham JM, et al. Clinical characteristics of ovarian cancer classified by BRCA1, BRCA2, and RAD51C status. Sci Rep. 2014;4:4026.

7. Ledermann J, Harter P, Gourley C, Friedlander M, Vergote I, Rustin G, et al. Olaparib maintenance therapy in platinum-sensitive relapsed ovarian cancer. N Engl J Med. 2012;366:1382-92.

8. Norquist BS, et al. Germline mutations in DNA repair genes in women with ovarian, peritoneal or fallopian tube cancer treated on GOG protocols 218 and 262. Presented at SGO 45th Annual Meeting on Women's Cancer 2014. 